\title{
The Potential Impact of Biofield Energy Treatment on the Physical and Thermal Properties of Silver Oxide Powder
}

\author{
Mahendra Kumar Trivedi ${ }^{1}$, Rama Mohan Tallapragada ${ }^{1}$, Alice Branton ${ }^{1}$, Dahryn Trivedi ${ }^{1}$, Gopal \\ Nayak $^{1}$, Omprakash Latiyal ${ }^{2}$, Snehasis Jana ${ }^{2, *}$ \\ ${ }^{1}$ Trivedi Global Inc., Henderson, USA \\ ${ }^{2}$ Trivedi Science Research Laboratory Pvt. Ltd., Hall-A, Chinar Mega Mall, Chinar Fortune City, Hoshangabad Rd., Bhopal, Madhya \\ Pradesh, India
}

Email address:

publication@trivedisrl.com (S. Jana)

\section{To cite this article:}

Mahendra Kumar Trivedi, Rama Mohan Tallapragada, Alice Branton, Dahryn Trivedi, Gopal Nayak, Omprakash Latiyal, Snehasis Jana. The Potential Impact of Biofield Energy Treatment on the Physical and Thermal Properties of Silver Oxide Powder. International Journal of Biomedical Science and Engineering. Vol. 3, No. 5, 2015, pp. 62-68. doi: 10.11648/j.ijbse.20150305.11

\begin{abstract}
Silver oxide has gained significant attention due to its antimicrobial activities. The purpose of this study was to evaluate the impact of biofield energy treatment on the physical and thermal properties of silver oxide $\left(\mathrm{Ag}_{2} \mathrm{O}\right)$. The silver oxide powder was divided into two parts, one part was kept as control and another part was received Mr. Trivedi's biofield energy treatment. The control and treated samples were analyzed using X-ray diffraction (XRD), differential scanning calorimetry (DSC), thermogravimetric analysis (TGA), and Fourier transform infrared (FT-IR) spectroscopy. The XRD diffractogram showed that the crystallite size of treated sample was significantly altered on the planes (200), (311), and (220) by 100, 150 and $-25 \%$ respectively, with respect to control. The DSC result exhibited that the thermal energy required to decompose the silver oxide to silver and oxygen was altered from -12.47 to $71.58 \%$ in treated samples as compared to the control. TGA showed that the onset temperature of thermal degradation was reduced from $335^{\circ} \mathrm{C}$ (control) to $322.4^{\circ} \mathrm{C}$. In addition, the rate of weight loss in treated sample was increased by $4.14 \%$ as compared to the control. Besides, the FT-IR did not show any alteration in absorption wavenumber of treated sample as compared to the control. Hence, the XRD, DSC and TGA data revealed that the biofield energy treatment has a significant impact on the physical and thermal properties of silver oxide powder. Therefore, the biofield energy treatment might improve the dissolution rate in formulation and bioavailability of treated silver oxide as compared to control.
\end{abstract}

Keywords: Silver Oxide, Biofield Energy Treatment, X-Ray Diffraction, Differential Scanning Calorimetry, Thermogravimetric Analysis, Fourier Transform Infrared Spectroscopy

\section{Introduction}

Silver $(\mathrm{Ag})$ is a naturally occurring ductile and malleable element. It has higher thermal and electrical conductivity among all metals [1]. In addition, metallic silver has been used in several medical application which includes surgical prosthesis and splints, and coinage [2]. The antibacterial properties of silver is known to world from ancient times [3]. Recently, silver compounds such as silver chloride, silver nitrate, and silver oxide also gained significant attention due to their antimicrobial properties [4]. Allahverdiyev et al. reported that the silver oxide has an antibacterial effect against drug-resistant bacteria and leishmania parasites [5] Also, the presence of silver oxide in glassy system showed its significant effect against Eschierchia coli and Salmonella and Pseudomonas bacteria [6]. It is also reported that the efficacy of drug is highly depends on their physical and thermal properties $[7,8]$. Thus, it is important to study a treatment strategy i.e. biofield energy treatment, which may modify the physical and thermal properties of the silver oxide. The National center for Complementary and alternative medicine (NCCAM) has recommended uses of alternative CAM therapies (e.g. healing therapy) in the healthcare sector [9]. Besides, a human has the capability to harness the energy from the environment/Universe and transmit it to any object around the Globe. The object(s) receive the energy and respond into a useful way that is called biofield energy, and this process is known as biofield energy treatment. Mr. 
Trivedi's unique biofield energy treatment (The Trivedi Effect ${ }^{\mathbb{R}}$ ) had been studied in various scientific fields such as material science [10-12], microbiology [13] and agricultural [14]. The biofield energy treatment has significantly altered the physical and thermal properties in cadmium [15] and magnesium [16]. Recently, our group reported that biofield treatment has altered the bond length of Ti-O in barium titanate [17]. Therefore, based on excellent outcomes with biofield energy treatment on metals and ceramics, this work was undertaken to evaluate the effect of this treatment on the physical and thermal properties of the silver oxide powder using X-ray diffraction (XRD), differential scanning calorimetry (DSC), thermogravimetric analysis (TGA), and Fourier transform infrared (FT-IR) spectroscopy.

\section{Materials and Methods}

Silver oxide powder was procured from Sigma Aldrich, USA. The procured powder was divided into two parts coded as control and treated. The control part was remained the same and the treated part was in sealed pack, handed over to Mr. Trivedi for biofield energy treatment under standard laboratory condition. Mr. Trivedi provided the treatment through his energy transmission process to the treated sample without touching the sample. After that, the control and treated samples were characterized by using XRD, DSC, TGA, and FT-IR techniques.

\subsection{XRD Study}

The XRD analysis of control and treated silver oxide was performed on Phillips, Holland PW 1710 X-ray diffractometer system. The x-ray of wavelength $1.54056 \AA$ was used. From the XRD diffractogram, peak intensity counts, $d$ value $(\AA)$, full width half maximum (FWHM) $\left(\theta^{\circ}\right)$, relative intensity $(\%)$ were obtained. The crystal structure parameters such as lattice parameter, unit cell volume of control and treated were computed using PowderX software.

The crystallite size (D) was calculated by using Scherrer equation as following:

$$
\mathrm{D}=\mathrm{k} \lambda /(\mathrm{b} \operatorname{Cos} \theta)
$$

Here, $\lambda=1.54056 \AA, \mathrm{b}$ is full width half maximum (FWHM) of peaks and $\mathrm{k}$ is the equipment constant $(=0.94)$.

The percentage change in crystallite size was calculated using following formula:

$$
\% \text { change in crystallite size }=\left[\left(\mathrm{D}_{\mathrm{t}}-\mathrm{D}_{\mathrm{c}}\right) / \mathrm{D}_{\mathrm{c}}\right] \times 100
$$

Where, $D_{c}$ and $D_{t}$ are crystallite size of control and treated powder samples respectively.

\subsection{Thermal Analysis}

The thermal analysis of silver oxide powder was performed using DSC and TGA-DTA. For DSC analysis, Pyris-6 Perkin Elmer DSC at a heating rate of $10^{\circ} \mathrm{C} / \mathrm{min}$ with nitrogen atmosphere, was used. The thermal decomposition temperature and thermal energy of the samples were obtained from the DSC curve. The percentage change in thermal energy $(\Delta \mathrm{H})$ was calculated using following equation:

$$
\begin{aligned}
& \% \text { change in thermal energy }(\Delta \mathrm{H}) \\
& =\frac{\left[\Delta \mathrm{H}_{\text {Treated }}-\Delta \mathrm{H}_{\text {Control }}\right]}{\Delta \mathrm{H}_{\text {Control }}} \times 100
\end{aligned}
$$

Where, $\Delta \mathrm{H}_{\text {Control }}$ and $\Delta \mathrm{H}_{\text {Treated }}$ are the latent heat of fusion of control and treated samples, respectively. Besides, for TGA analysis, Mettler Toledo simultaneous TGA-DTA was used to analyze the thermal characteristics of silver oxide powder. The samples were heated from room temperature to $900^{\circ} \mathrm{C}$ with a heating rate of $10^{\circ} \mathrm{C} / \mathrm{min}$ under nitrogen atmosphere.

\subsection{FT-IR Spectroscopy}

FT-IR spectra were recorded on Shimadzu's Fourier transform infrared spectrometer (Japan) with frequency range of $4000-500 \mathrm{~cm}^{-1}$. The analysis was accomplished to evaluate the effect of biofield treatment on dipole moment, force constant and bond strength in chemical structure.

\section{Results and Discussion}

\subsection{XRD Study}

The XRD is a non-destructive and quantitative technique, which has been extensively used to study the crystal structure and its parameters of a compound. The XRD diffractogram of control and treated silver oxide samples is shown in Figure 1. It can be observed that the control sample showed the crystalline peaks at Bragg angle (20) $32.72^{\circ}, 37.95^{\circ}, 54.78^{\circ}$, $65.28^{\circ}$ and $68.6^{\circ}$ which were attributed to the crystalline planes (111), (200), (220), (311), and (222) according to Joint committee on powder diffraction standards (JCPDS) file no. 12-0793 [18]. The treated sample also exhibited the similar peaks at Bragg angle $32.72^{\circ}, 37.97^{\circ}, 54.78^{\circ}, 65.31^{\circ}$, and $68.59^{\circ}$. These peak suggested the cubic crystal structure of the silver oxide in control and treated sample. Furthermore, the crystallite size was computed on each crystalline planes and presented in Table 1. Data showed that the crystallite size of treated silver oxide was altered on the crystalline plane (200), (220) and (311). The crystallite size was found as 72.9 $\mathrm{nm}$ and $98.4 \mathrm{~nm}$ on planes (200) and (311) respectively in control sample, while it was significantly increased to 145.9 $\mathrm{nm}$ and $245.9 \mathrm{~nm}$ respectively in treated sample. Furthermore, the crystallite size on plane (220) was decreased from $155.4 \mathrm{~nm}$ (control) to $116.6 \mathrm{~nm}$ in treated silver oxide sample after biofield treatment. It indicated that the crystallite size of treated sample was significantly altered by $100 \%,-25 \%$, and $150 \%$ on crystalline planes (200), (220), and (311) as compared to the control (Figure 2). However, the crystallite size on planes (111) and (222) were showed same crystallite size in control and treated sample. In cubic crystals system the planes (111) and (222) are parallel to each other, thus both planes showed similar behavior. Subhan et al. reported that the crystallite size of silver oxide 
nanocomposite was increased after annealing at high temperature [19]. In addition, it was also reported that the reduction in dislocation density in silver oxide leads to increase the crystallite size [20]. Thus, it assumed that the biofield energy treatment probably altered the dislocation density on plane (200), (220) and (311) and that might be responsible for the alteration in the crystallite size along these planes. Furthermore, it is reported that the alteration in crystallite size affects the solubility of drugs in fluids [21]. Thus, it is assumed that the alteration in crystallite size in treated sample might influence the solubility of silver oxide in topical formulation, rate of penetration and bioavailability across the skin. Moreover, the XRD data of the control and treated silver oxides were analyzed using PowderX software and results are presented in Table 2. The data showed that lattice parameter and unit cell volume were slightly reduced in treated sample as compared to control. The density data showed minimal increase $(0.029 \%)$, whereas molecular weight data showed minimal decrease $(0.031 \%)$ in treated sample as compared to the control. Thus, crystal structure parameters did not show any significant alteration in treated sample as compared to the control.
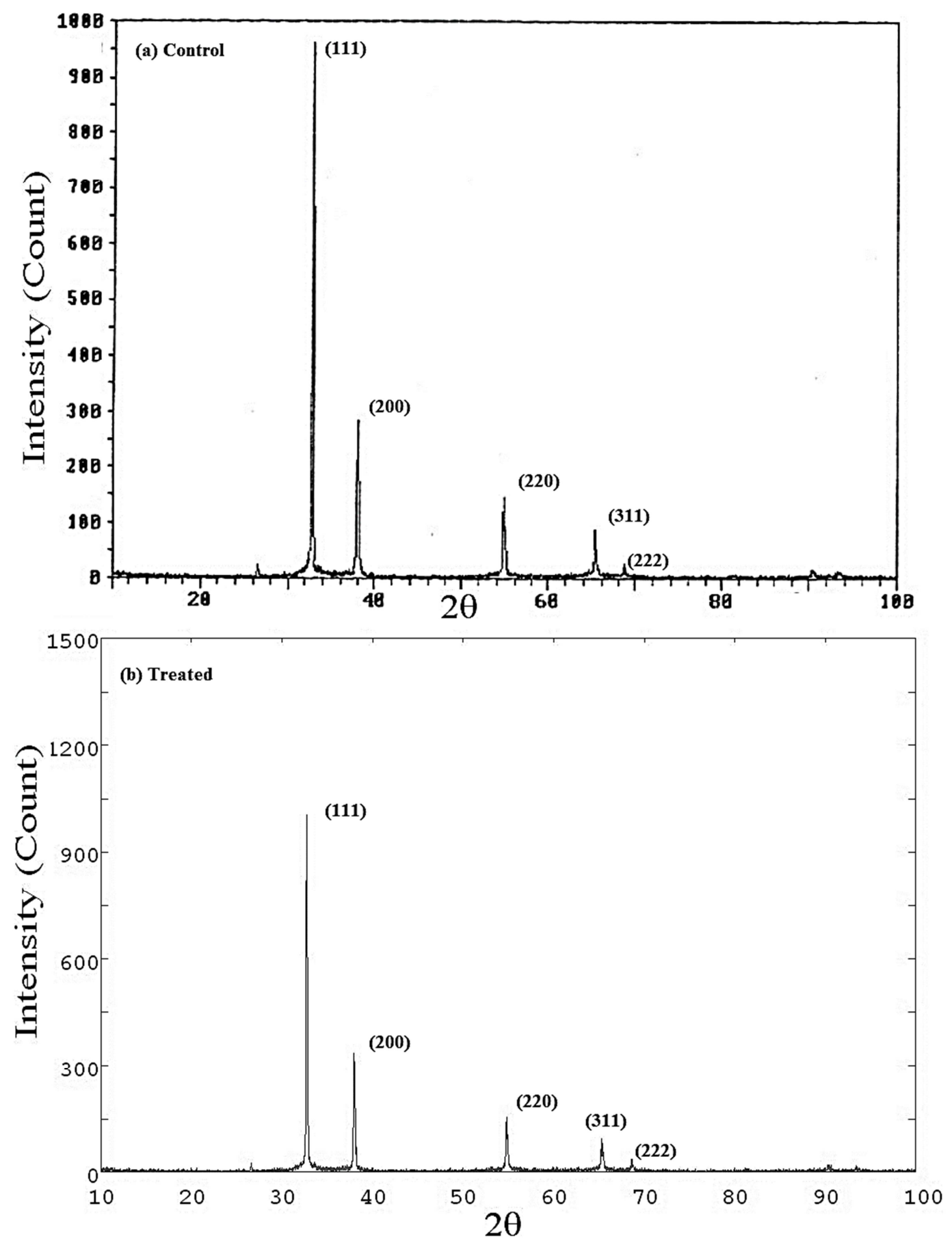

Fig. 1. X-ray diffractogram of silver oxide powder. 
Table 1. The crystallite size and plane analysis of silver oxide powder.

\begin{tabular}{|c|c|c|c|c|c|c|}
\hline \multirow{2}{*}{ Plane (hkl) } & \multicolumn{3}{|l|}{ Control } & \multicolumn{3}{|l|}{ Treated } \\
\hline & Bragg's angle $\left(2 \theta^{\circ}\right)$ & FWHM (degree) & Crystallite size (nm) & Bragg's angle $\left(2 \theta^{\circ}\right)$ & FWHM (degree) & Crystallite size (nm) \\
\hline 111 & 32.72 & 0.12 & 86.3 & 32.72 & 0.12 & 86.3 \\
\hline 200 & 37.95 & 0.14 & 72.9 & 37.97 & 0.08 & 145.9 \\
\hline 220 & 54.78 & 0.08 & 155.4 & 54.78 & 0.10 & 116.6 \\
\hline 311 & 65.28 & 0.12 & 98.4 & 65.31 & 0.06 & 245.9 \\
\hline 222 & 68.60 & 0.10 & 125.3 & 68.59 & 0.1 & 125.3 \\
\hline
\end{tabular}

FWHM: Full width half maximum of XRD peak

Table 2. Effect of biofield energy treatment on lattice parameter, unit cell volume density atomic weight, nuclear charge per unit volume of silver oxide powder.

\begin{tabular}{lllll}
\hline Group & Lattice parameter $(\AA)$ & Unit cell volume $\left(\times \mathbf{1 0}^{-\mathbf{2 3}} \mathbf{~ c m}^{\mathbf{3}}\right)$ & Density $(\mathbf{g} / \mathbf{c c})$ & Molecular weight $(\mathbf{g} / \mathbf{m o l})$ \\
\hline Control & 4.7363 & 10.6250 & 7.31319 & 234.00145 \\
Treated (T1) & 4.7359 & 10.6217 & 7.31546 & 233.92877 \\
Percent Change & -0.01 & -0.030 & 0.029 & -0.031 \\
\hline
\end{tabular}

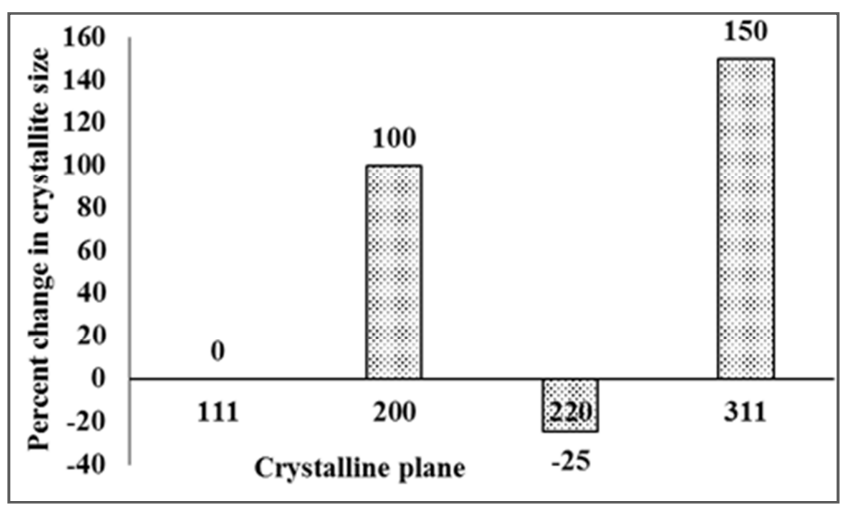

Fig. 2. Effect of biofield energy treatment on crystallite size along crystalline planes of silver oxide powder.

\subsection{Thermal Analysis}

Table 3. Differential scanning calorimetry (DSC) analysis of silver oxide powder.

\begin{tabular}{lllll}
\hline Parameter & Control & T1 & T2 & T3 \\
\hline Onset $\left({ }^{\circ} \mathrm{C}\right)$ & 381.12 & 383.40 & 383.16 & 380.51 \\
Peak $\left({ }^{\circ} \mathrm{C}\right)$ & 401.52 & 401.51 & 398.74 & 395.07 \\
Endset $\left({ }^{\circ} \mathrm{C}\right)$ & 414.17 & 420.59 & 414.56 & 403.98 \\
$\Delta \mathrm{H}(\mathrm{J} / \mathrm{g})$ & 132.94 & 228.10 & 158.77 & 116.35 \\
Percent change in $\Delta \mathrm{H}$ & - & 71.58 & 19.42 & -12.47 \\
\hline
\end{tabular}

The DSC analysis data of control and treated silver oxide samples are presented in Table 3. The DSC thermogram of control silver oxide showed a broad endothermic peak, which started from temperature (onset) $381.12{ }^{\circ} \mathrm{C}$ and ended at $414.17^{\circ} \mathrm{C}$. It is reported that the silver oxide decomposed to silver and oxygen at temperature around $400{ }^{\circ} \mathrm{C}$ [22]. Thus, the endothermic peak found in control sample was due to decomposition of silver oxide. The control sample showed the peak temperature for this process at $401.52^{\circ} \mathrm{C}$. Furthermore, the treated samples $\mathrm{T} 1, \mathrm{~T} 2$, and $\mathrm{T} 3$ were started to decompose at $383.40^{\circ} \mathrm{C}, 383.16^{\circ} \mathrm{C}$, and $380.51^{\circ} \mathrm{C}$ respectively. It indicated that the onset temperature was slightly increased by $2.28^{\circ} \mathrm{C}$ and $2.06^{\circ} \mathrm{C}$ in $\mathrm{T} 1$ and $\mathrm{T} 2$ respectively, however it was slightly decreased by $0.61^{\circ} \mathrm{C}$ in
$\mathrm{T} 3$ as compared to the control. Moreover, the endset of this decomposition process was found at $420.59^{\circ} \mathrm{C}, 414.56^{\circ} \mathrm{C}$, and $403.98^{\circ} \mathrm{C}$ in $\mathrm{T} 1, \mathrm{~T} 2$, and $\mathrm{T} 3$ respectively. In addition, the peak temperature of this process was observed at $401.51^{\circ} \mathrm{C}$, $398.74^{\circ} \mathrm{C}$, and $395.07^{\circ} \mathrm{C}$ in treated samples $\mathrm{T} 1, \mathrm{~T} 2$, and $\mathrm{T} 3$ respectively. The energy absorbed by the control sample in the decomposition of silver oxide was $132.94 \mathrm{~J} / \mathrm{g}$ and it was changed to $228.10 \mathrm{~J} / \mathrm{g}, 158 / 77 \mathrm{~J} / \mathrm{g}$, and $116.35 \mathrm{~J} / \mathrm{g}$ in treated in $\mathrm{T} 1, \mathrm{~T} 2$, and $\mathrm{T} 3$, respectively. It indicated that the energy utilized in the decomposition of silver oxide in $\mathrm{T} 1$ and $\mathrm{T} 2$ samples was $71.58 \%$ and $19.42 \%$ higher as compared to the control. On the contrary, the energy utilized in the decomposition of T3 sample was $12.47 \%$ lower with respect to the control. Nevertheless, the increase in thermal decomposition energy in treated sample (T1and T2) indicated that the thermal stability of silver oxide might increase after biofield energy treatment. Our group, previously reported that the biofield energy treatment had increased the latent heat of fusion in cadmium powder [15]. Thus, it is assumed that the energy, which probably transferred through biofield treatment, possibly altered the bonding strength in silver oxide. Furthermore, in order to study the change in weight of the sample during decomposition of silver oxide, the TGA analysis was carried out. The TGA thermogram of control and treated samples is presented in Figure 3. The analysis result of TGA are presented in Table 4. The data exhibited that the control sample start losing the weight at onset temperature $335.0^{\circ} \mathrm{C}$ and stopped at endset temperature $407.0^{\circ} \mathrm{C}$. However, in treated sample the onset and endset temperature were found at $322.45^{\circ} \mathrm{C}$ and $411.69^{\circ} \mathrm{C}$ respectively. Based on this data, the peak width i.e. the difference of onset and endset temperature, was found as $72^{\circ} \mathrm{C}$ in control sample and it was significantly increased to $89.24^{\circ} \mathrm{C}$ in treated silver oxide sample. In this decomposition process, the control and treated samples were lost 6.61 and $6.96 \%$ of its initial weight respectively. Also the rate of weight loss during decomposition was increased from 1.69 $\times 10^{-6} \mathrm{~g} / \mathrm{s}$ (control) to $1.76 \times 10^{-6} \mathrm{~g} / \mathrm{s}$ in treated silver oxide sample. It indicated that rate of weight loss during decomposition of silver oxide was increased by $4.14 \%$. The 
increase in decomposition energy in DSC and rate of weight loss in TGA are contrary to each other. It is possible that the biofield energy altered the interatomic interaction in silver oxide, which resulted into change in the rate of weight loss during decomposition. It is reported that the change in thermal characteristics can influenced the rate of dissolution of a drug [23]. Thus, it is assumed that the change in thermal characteristic of treated silver oxide might improve its rate of dissolution in formulation and thus bioavailability.
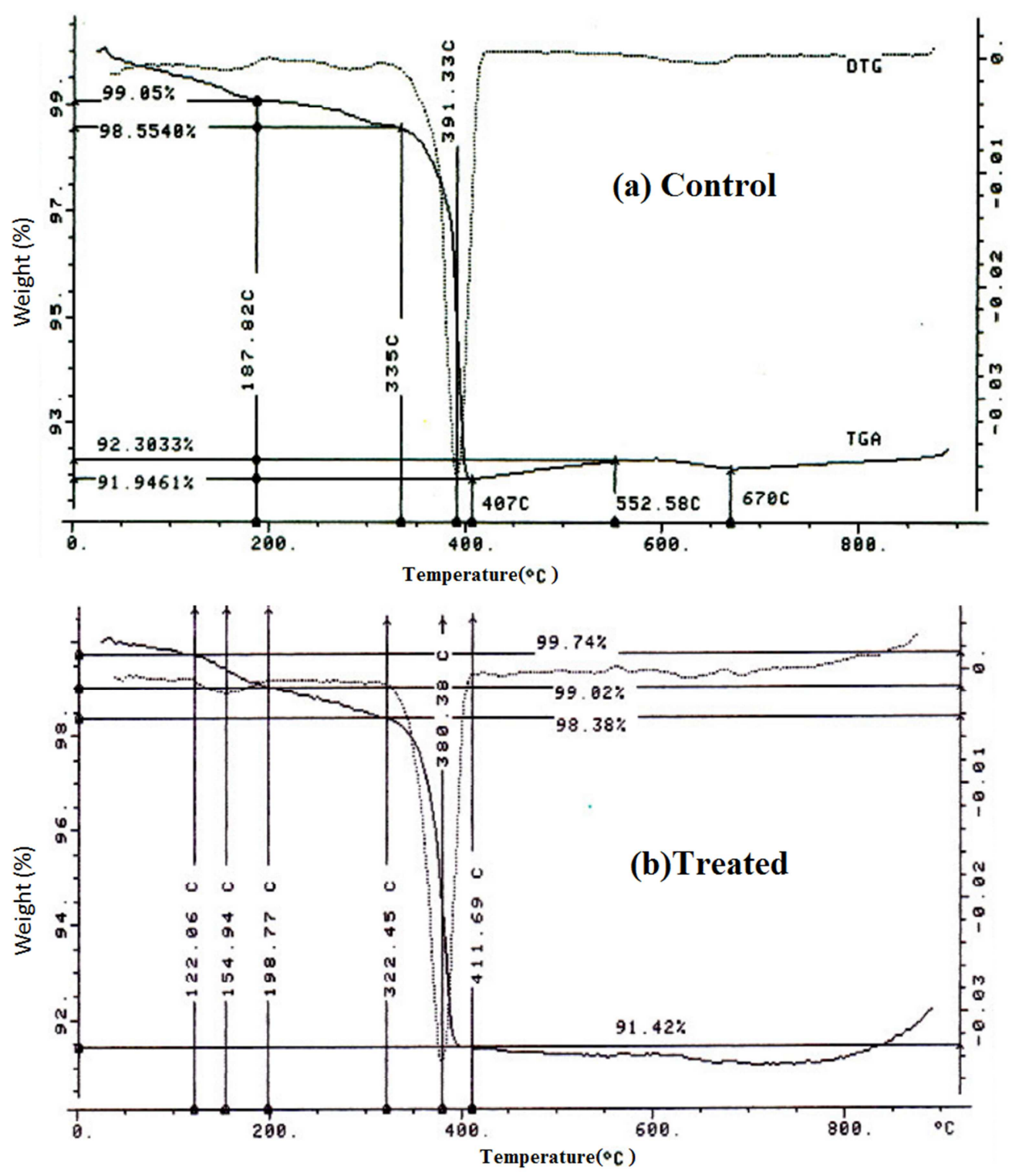

Fig. 3. TGA thermogram of silver oxide.

Table 4. TGA analysis of silver oxide powder.

\begin{tabular}{lll}
\hline Parameter & Control & T1 \\
\hline Onset temperature $\left({ }^{\circ} \mathrm{C}\right)$ & 335.00 & 322.45 \\
Peak temperature $\left({ }^{\circ} \mathrm{C}\right)$ & 391.33 & 380.38 \\
Endset temperature $\left({ }^{\circ} \mathrm{C}\right)$ & 407.00 & 411.69 \\
Peak width $\left({ }^{\circ} \mathrm{C}\right)$ & 72.00 & 89.24 \\
Weight of the sample at onset $(\%)$ & 98.55 & 98.38 \\
Weight of the sample at endset $(\%)$ & 91.95 & 91.42 \\
Change in weight $(\%)$ & -6.61 & -6.96 \\
Percent change in weight/width & -0.09 & -0.08 \\
Weight loss rate $(\mathrm{g} / \mathrm{s}) \times 10^{-6}$ & -1.69 & -1.76 \\
Percent change in weight loss rate $(\%)$ & - & 4.14 \\
\hline
\end{tabular}

\subsection{FT-IR Spectroscopy}

The FT-IR spectra of control and treated silver oxide samples are presented in Figure 4. The control and treated samples showed the band at $3190 \mathrm{~cm}^{-1}$, which was attributed to $\mathrm{O}-\mathrm{H}$ stretching vibrations. It could be due to moisture absorption by the samples from the environment. In addition, the band observed at $1487 \mathrm{~cm}^{-1}$ in control and $1484 \mathrm{~cm}^{-1}$ in treated sample were due to $\mathrm{C}=\mathrm{O}$ stretching vibrations [24]. It could be due to $\mathrm{CO}_{2}$ absorption by the sample from the environment. The characteristic band of silver oxide bond was observed at $547 \mathrm{~cm}^{-1}$ in control and treated sample [25]. Thus, the FT-IR data did not show any significant alteration 
in absorption wavenumbers of treated sample as compared to the control.
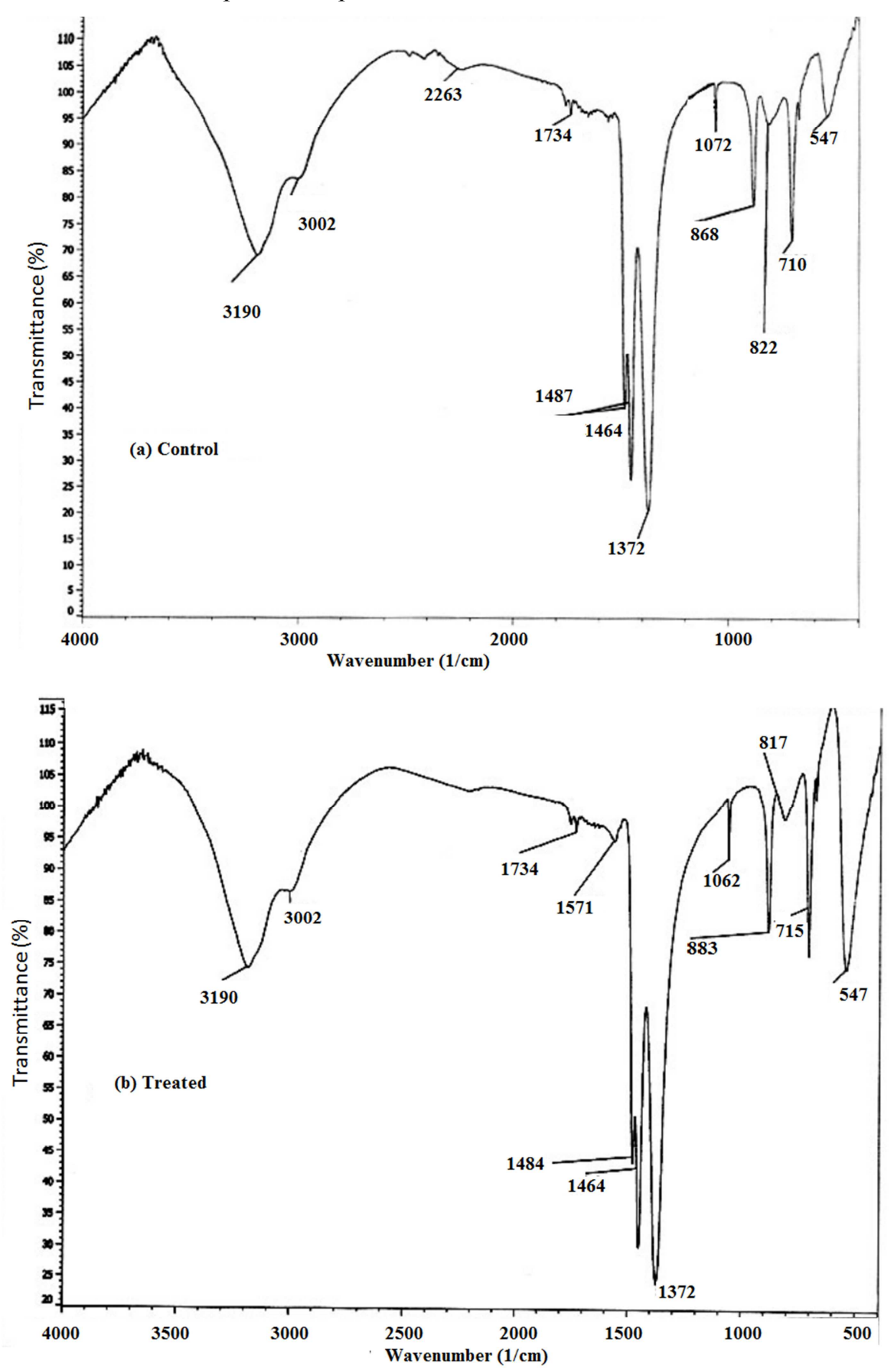

Fig. 4. FT-IR spectra of silver oxide powder.

\section{Conclusions}

The XRD data showed that the crystallite size was significantly increased upto $150 \%$ as compared to the control. The DSC data revealed that the thermal decomposition energy of silver oxide was increased up to $71.58 \%$ in treated sample as compared to the control. TGA data exhibited that the rate of weight loss due to decomposition of silver oxide was increased by $4.14 \%$ in treated sample as compared to the control. Hence, the biofield treatment has significantly altered the physical and thermal properties of silver oxide. Based on the alteration, it is assumed that biofield energy treatment could be applied to silver oxide to improve its dissolution rate in topical formulation and bioavailability.

\section{Acknowledgments}

Authors thank Dr. Cheng Dong of NLSC, Institute of Physics, and Chinese academy of sciences for permitting us to use Powder-X software for analyzing XRD results. The 
authors would also like to thank Trivedi Science, Trivedi Master Wellness and Trivedi Testimonials for their support during the work.

\section{References}

[1] Nordberg G, Gerhardsson L (1988) Silver. In: Handbook on toxicity of inorganic compounds. Marcel Dekker Inc, New York.

[2] Drake PL, Hazelwood KJ (2005) Exposure-related health effects of silver and silver compounds: A Review Ann Occup Hyg 49: 575-585.

[3] Hill WR, Pillsbury DM (1939) Argyria: The pharmacology of silver. Baltimore, MD: Williams \& Wilkins Company.

[4] Feng QL, Wu J, Chen GQ, Cui FZ, Kim TN, et al (2000) A mechanistic study of the antibacterial effect of silver ions on Escherichia coli and Staphylococcus aureus. J Biomed Mater Res A 52: 662-668.

[5] Allahverdiyev AM, Abamor ES, Bagirova M, Rafailovich M (2011) Antimicrobial effects of $\mathrm{TiO}_{2}$ and $\mathrm{Ag}_{2} \mathrm{O}$ nanoparticles against drug-resistant bacteria and leishmania parasites. Future Microbiol 6: 933-940.

[6] Stefan R, Spinu M, Popescu S, Taralunga G (2010) Vitreous system $\mathrm{Ag}_{2} \mathrm{O}-\mathrm{ZnO}-\mathrm{B}_{2} \mathrm{O}_{3}$ action against Gram negative bacteria. Anim Sci Biotechnol 43:433-436.

[7] Eichelbaum MF, Testa B, Somogyi A (2012) Stereochemical aspects of drug action and disposition. Springer Science \& Business Media: Medical.

[8] Omelczuk MO, McGinity JW (1993) The influence of thermal treatment on the physical-mechanical and dissolution properties of tablets containing poly (DL-lactic acid). Pharm Res 10: 542-548.

[9] Barnes PM, Powell-Griner E, McFann K, Nahin RL (2004) Complementary and alternative medicine use among adults: United States, 2002. Adv Data 343: 1-19.

[10] Trivedi MK, Nayak G, Patil S, Tallapragada RM, Latiyal O (2015) Studies of the atomic and crystalline characteristics of ceramic oxide nano powders after bio field treatment. Ind Eng Manage 4: 161 .

[11] Trivedi MK, Patil S, Nayak G, Jana S, Latiyal O (2015) Influence of biofield treatment on physical, structural and spectral properties of boron nitride. J Material Sci Eng 4: 181.

[12] Trivedi MK, Patil S, Tallapragada RM (2013) Effect of biofield treatment on the physical and thermal characteristics of vanadium pentoxide powder. J Material Sci Eng S11: 001.
[13] Trivedi MK, Patil S, Shettigar H, Bairwa K, Jana S (2015) Phenotypic and Biotypic Characterization of Klebsiella oxytoca: An Impact of Biofield Treatment. J Microb Biochem Technol 7:202-205.

[14] Lenssen AW (2013) Biofield and fungicide seed treatment influences on soybean productivity, seed quality and weed community. Agricultural Journal 8: 138-143.

[15] Trivedi MK, Nayak G, Patil S, Tallapragada RM, Latiyal O et al.(2015) An evaluation of biofield treatment on thermal, physical and structural properties of cadmium powder. J Thermodyn Catal 6: 147.

[16] Trivedi MK, Tallapragada RM, Branton A, Trivedi D, Nayak $\mathrm{G}$, et al. (2015) Potential impact of biofield treatment on atomic and physical characteristics of magnesium. Vitam Miner 3: 129 .

[17] Trivedi MK, Nayak G, Patil S, Tallapragada RM, Latiyal O, et al. (2015) Impact of biofield treatment on atomic and structural characteristics of barium titanate powder. Ind Eng Manage 4: 166.

[18] Kim M, Kim S, Park H, Huh Y (2011) Morphological evolution of $\mathrm{Ag}_{2} \mathrm{O}$ microstructures from cubes to octapods and their antibacterial activities. Bull Korean Chem Soc 32: 37933795 .

[19] Subhan MA, Uddin N, Sarker P, Nakata H, Makioka R (2015) Synthesis, characterization, low temperature solid state $\mathrm{PL}$ and photocatalytic activities of $\mathrm{Ag}_{2} \mathrm{O} \cdot \mathrm{CeO}_{2} \cdot \mathrm{ZnO}$ nanocomposite. Spectrochim Acta A Mol Biomol Spectrosc 151:56-63.

[20] Reddy PN, Reddy MHP, Pierson JF, Uthanna S (2014) Characterization of silver oxide films formed by reactive RF sputtering at different substrate temperatures. ISRN Optics vol. 2014, Article ID 684317.

[21] Grassi M, Grassi G, Lapasin R (2006) Understanding drug release and absorption mechanisms: A physical and mathematical approach. Medical Italo Colombo CRC Press.

[22] Parkhurst WA, Dallek S, Larrick BF (1982) Thermogravimetric analysis of silver oxide mixtures (No. NSWC/TR-82-420). Naval Surface Weapons Center Silver Spring MD.

[23] Mirza S, Miroshnyk I, Habib MJ, Brausch JF, Hussain MD (2010) enhanced dissolution and oral bioavailability of piroxicam formulations: Modulating effect of phospholipids. Pharmaceutics 2: 339-350.

[24] Xiaa H, Yang G (2012) Facile synthesis of inorganic nanoparticles by a precipitation method in molten 3caprolactam solvent. J Mater Chem 22:18664-18670.

[25] Yong NL, Ahmad A, Mohammad AW (2013) Synthesis and characterization of silver oxide nanoparticles by a novel method. IJSER 4: 155-158. 